\title{
MANAJEMEN PERAWATAN DAN PEMELIHARAAN GEDUNG, ASET DAN FASILITAS DI UNIVERSITAS PALANGKA RAYA
}

\author{
Zerizkyeska Nugrahayu N. ${ }^{1}$, Dewantoro ${ }^{2}$ dan Apria Brita Pandohop Gawei ${ }^{3}$ \\ ${ }^{123}$ Program Studi Teknik Sipil, Fakultas Teknik, Universitas Palangka Raya \\ Email: zerizkyeskanrizali@gmail.com ${ }^{1}$, dewantoro@eng.upr.ac.id ${ }^{2}$, dan \\ apriagawei@jts.upr.ac.id ${ }^{3}$
}

\begin{abstract}
ABSTRAK
Aset dan fasilitas berupa bangunan gedung yang ada di Universitas Palangka Raya perlu dikelola dengan baik dan dilakukan perawatan serta pemeliharaan secara terjadwal. Perawatan dan pemeliharaan bangunan gedung bertujuan agar bangunan gedung dapat berfungsi dengan baik dan tetap laik fungsi serta memperpanjang umur bangunan dengan pemeriksaan secara teratur. Manajemen universitas belum sepenuhnya diterapkan dengan tepat. Kondisi fisik bangunan gedung UPR pada umumnya belum memiliki kualitas yang baik dan berorientasi jangka panjang sehingga mengurangi faktor efisiensi, keamanan dan kenyamanan penggunaannya, serta sarana dan prasarana pendidikan masih belum memadai. Penelitian ini bertujuan untuk mengetahui jenis bangunan gedung yang dimiliki UPR berdasarkan fungsi bangunan gedung dan mengetahui manajemen perawatan dan pemeliharaan gedung, aset, dan fasilitas di UPR berdasarkan Peraturan Menteri Pekerjaan Umum No. 24/PRT/M/2008. Data penelitian diperoleh dengan metode dokumentasi, observasi, dan wawancara kepada pihak pengelola bangunan gedung di UPR. Pengecekan keabsahan data menggukakan triangulasi. Metode analisis data model Miles dan Huberman digunakan daam menganalisis penelitian ini. Berdasarkan hasil penelitian, UPR memiliki bangunan gedung dengan fungsi hunian, fungsi usaha, fungsi sosial dan budaya, dan fungsi keagamaan. Dalam pelaksanaan pemeliharaan dan perawatan bangunan gedung, UPR sudah melakukan pemeliharaan dan perawatan bangunan gedung dengan rutin dan baik, namun dalam manajemen pemeliharaan dan perawatan bangunan gedung UPR belum sepenuhnya menerapkan peraturan yang berlaku.
\end{abstract}

Kata Kunci: manajemen, pemeliharaan, perawatan, bangunan gedung, aset.

\begin{abstract}
Assets and facilities in the form of buildings at the University of Palangka Raya need to be managed properly and maintenance and maintenance carried out on a scheduled basis. Building maintenance and maintenance aims to ensure that the building can function properly and remain functional and extend the life of the building with regular inspections. University management has not been fully implemented properly. The physical condition of UPR buildings in general does not have good quality and is long-term oriented so that it reduces the efficiency, safety and convenience of its use, and educational facilities and infrastructure are still inadequate. This study aims to determine the type of building owned by UPR based on the function of the building and to determine the management and maintenance of buildings, assets, and facilities at UPR based on the Regulation of
\end{abstract}


the Minister of Public Works No. 24/PRT/M/2008. The research data were obtained by means of documentation, observation, and interviews with the building management at UPR. The validity of the data was checked by triangulation technique. The Miles and Huberman data model analysis method is used in analyzing this research

Based on the research results, UPR has buildings with residential functions, business functions, social and cultural functions, and religious functions. In the implementation of building maintenance and maintenance, UPR has carried out routine and good maintenance and maintenance of buildings, but in the management of building maintenance and maintenance, UPR has not fully implemented the applicable regulations.

Key word: management, maintenance, maintenance, buildings, assets.

\section{PENDAHULUAN}

Universitas Palangka Raya (UPR) adalah sebuah universitas negeri yang memiliki posisi strategis karena berdiri di Kota Palangka Raya yang merupakan ibukota Provinsi Kalimantan Tengah. Bangunan gedung merupakan suatu fasilitas yang dibuat oleh manusia untuk menunjang berbagai aktifitas kegiatan. Bertambahnya umur konstruksi dan kegiatan yang dilakukan setiap harinya menyebabkan kerusakan dan penurunan kualitas pada bangunan gedung. Secara kuantitatif, UPR telah mengalami peningkatan yang sangat signifikan. Jumlah gedung perkantoran dan perkuliahan serta sarana dan prasarana pendidikan terus mengalami peningkatan. Namun, secara kualitatif UPR masih belum berkembang secara maksimal, ha ini terlihat dari manajemen universitas yang belum sepenuhnya diterapkan dengan tepat. Telah dilakukan beberapa penelitian dengan tujuan untuk mengetahui manajemen perawatan dan pemeliharaan bangunan gedung, dalam hal ini penulis berfokus pada manajemen perawatan dan pemeliharaan bangunan gedung, aset, dan fasilitas di Universitas Palangka Raya.

\section{Tujuan Penelitian}

Tujuan dari penelitian ini adalah untuk mengetahui mengetahui jenis bangunan gedung yang dimiliki UPR berdasarkan fungsi bangunan gedung dan mengetahui manajemen perawatan dan pemeliharaan gedung, aset, dan fasilitas di UPR berdasarkan Peraturan Menteri Pekerjaan Umum No. 24/PRT/M/2008.

\section{METODE PENELITIAN}

\section{Lokasi Penelitian}

Penelitian ini dilakukan dilakukan kepada pihak pengelola kegiatan pemeliharaan dan perawatan bangunan gedung, aset dan fasilitas di Universitas Palangka Raya.

\section{Keabsahan Data dan Analisis Data}

Dalam teknik pemeriksaan keabsahan data, penulis menggunakan tiga cara, yaitu :

1. Triangulasi

2. Ketekunan Pengamatan

3. Diskusi 
Teknik analisis data yang digunakan dalam penelitian ini adalah konsep analisis data interaktif Miles dan Huberman, yaitu:

1. Pengumpulan data (data collection

2. Penyajian data (data display)

3. Penarikan kesimpulan (conclusion)

\section{Metode Pengumpulan Data}

Metode pengumpulan data dilakukan dengan cara:

1. Metode wawancara yaitu dengan mengajukan kepada informan penelitian.

2. Metode dokumentasi yaitu dengan mencatat dan menelaah dokumendokumen yang berisikan peraturan-peraturan, intruksi, laporan, rekaman yang dilakukan peneliti kepada informan penelitian, dan memadukan hasil wawancara dengan dokumen-dokumen yang ada.

3. Metode observasi yaitu dengan melakukan pengamatan langsung ke lokasi penelitian.

\section{Tahapan Penelitian}

Penelitian ini dilakukan dalam lima tahap, dimana setiap tahapannya memiliki hubungan yang saling mempengaruhi. Secara lengkap tahapan penelitan dijelaskan sebagai berikut:

\section{Tahap Pertama}

Tahap pertama pada penelitian ini adalah tahap pendahuluan. Kegiatan-kegiatan yang dilakukan pada tahap ini, adalah:

1. Menyusun latar belakang penelitian

2. Menyusun rumusan masalah

3. Menyusun tujuan penelitian

4. Menyusun batasan masalah

5. Menyusun manfaat penelitian

\section{Tahap Kedua}

Tahap kedua pada penelitian ini adalah tahap untuk melakukan review literatur, yaitu :

1. Pengertian Manajemen

2. Pengertian Bangunan Gedung, Aset dan Fasilitas Bangunan Gedung

3. Pengertian Pemeliharaan dan Perawatan Bangunan Gedung

4. Lingkup Pemeliharaan dan Perawatan Bangunan Gedung

5. Penelitian Terdahulu

\section{Tahap Ketiga}

Tahap ketiga pada penelitian ini adalah tahap melakukan pengumpulan data. Kegiatan-kegiatan yang dilakukan pada tahap ini yaitu :

1. Menentukan Pendekatan Penelitian

2. Menentukan Metode Pengumpulan Data

3. Menentukan Waktu dan Lokasi Penelitian

4. Menentukan Jenis dan Sumber Data

5. Melakukan Teknik Pengumpulan Data

6. Melakukan Penelitian 


\section{Tahap Keempat}

Tahap keempat pada penelitian ini adalah tahap pengolahan data untuk melakukan analisis data :

1. Reduksi Data (Data Reduction)

2. Penyajian Data (Data Display)

3. Kesimpulan (Conclusion/Verification)

Output yang dihasilkan pada tahap ini adalah hasil penelitian.

\section{Tahap Kelima}

Tahap kelima adalah tahap pengambilan kesimpulan dan saran terhadap penulisan skripsi. jurnal dari hasil penelitian yang dilakukan. Output yang dihasilkan berupa kesimpulan dan saran.

\section{Tahapan Analisis Data}

Tahapan dalam menganalisis data dalam penelitian ini yaitu:

1. Menganalisis profil bangunan gedung di UPR

2. Menganalisis manajemen perawatan dan pemeliharaan bangunan gedung di UPR

3. Menganalisis manajemen perawatan dan pemeliharaan bangunan gedung menurut PermenPU No. 24 Tahun 2008

4. Menganalisis perbandingan manajemen perawatan dan pemeliharaan bangunan gedung di UPR berdasarkan PermenPU No. 24 Tahun 2008

\section{HASIL \& PEMBAHASAN}

\section{Profil Bangunan Gedung Universitas Palangka Raya}

Berdasarkan hasil penelitian yang dilakukan penulis, diketahui bahwa bangunan gedung di Universitas Palangka Raya terdiri dari bangunan dengan fungsi sebagai berikut:

1. Bangunan dengan fungsi hunian

Bangunan dengan fungsi hunian bertujuan untuk memenuhi kebutuhan manusia akan papan/tempat tinggal. Dalam hal ini, Universitas Palangka Raya memiliki bangunan Perumahan Dinas untuk Dosen Golongan II.

2. Bangunan dengan fungsi usaha

Bangunan dengan fungsi sebagai usaha didirikan untuk mendukung aktifitas komersial meliputi jual, beli, sewa, dan kerjasama. Faktor lokasi yang strategis memegang peranan penting bagi kesuksesan bangunan tersebut. Contoh bangunan dengan fungsi usaha adalah bangunan perkantoran, dalam hal ini Rektorat Universitas Palangka Raya.

3. Bangunan dengan fungsi sosial dan budaya

Bangunan dengan fungsi sosial dan budaya memiliki fungsi utama sebagai tempat melakukan kegiatan sosial dan budaya yang meliputi bangunan pendidikan, pelayanan kesehatan, kebudayaan, laboratorium, dan bangunan gedung pelayanan umum. Contoh bangunan dengan fungsi sosial dan budaya yang dimiliki Universitas Palangka Raya antara lain:

Pendidikan : Gedung Perkuliahan

Pelayanan Kesehatan : Klinik Kesehatan 
Kebudayaan

Laboratorium

Pelayanan Umum
: $\quad$ GORSENI (Gelanggang Olahraga dan Seni)

Universitas Palangka Raya

: Laboratorium Jalan Raya Fakultas Teknik

Universitas Palangka Raya

: Rektorat Universitas Palangka Raya, BEM

Universitas Palangka Raya

4. Bangunan dengan fungsi keagamaan

Bangunan dengan fungsi keagamaan ditujukan untuk memenuhi kebutuhan batin manusia sebagai makhluk yang memiliki Tuhan. Bangunan dengan fungsi keagaaman yang dimiliki Universitas Palangka Raya adalah Gereja Mahanam, Masjid Shalahuddin, dan Mushola Fakultas Teknik.

Setiap bangunan gedung yang ada di Universitas Palangka Raya adalah aset dari Universitas Palangka Raya.

\section{Manajemen Perawatan dan Pemeliharaan Bangunan Gedung di UPR}

Dalam mengelola aset dan fasilitas berupa bangunan tersebut, Universitas Palangka Raya memberikan tugas kepada Sub Bagian Rumah Tangga Universitas Palangka Raya. Mengingat jumlah bangunan yang banyak, dalam pengelolaan nya Sub Bagian Rumah Tangga dibantu oleh Unit pengguna bangunan gedung seperti Fakultas/Lembaga. Terdapat dua pilihan alur dalam proses manajemen perawatan dan pemeliharaan bangunan gedung di Universitas Palangka Raya:

1. Unit (Fakultas/Lembaga) sebagai pengguna bangunan gedung dapat membuat usulan yang ditujukan langsung ke Sub Bagian Rumah Tangga, kemudian akan diproses dengan mempertimbangkan anggaran dan tingkat prioritas kebutuhan akan perawatan dan pemeliharaan. Jika diketahui anggaran yang ada di Unit masih tersedia, maka akan direkomendasikan kembali kepada Unit untuk melakukan pemeliharaan dan perawatan dengan anggaran yang tersedia di Unit. Namun, jika anggaran yang ada di Unit sudah tidak ada, dan anggaran yang tersedia di Sub Bagian Rumah Tangga masih mencukupi untuk melakukan pemeliharaan dan perawatan, maka akan langsung ditindaklanjuti oleh Sub Bagian Rumah Tangga. Setelah selesai, data dari bangunan gedung yang diusulkan untuk pemeliharaan dan perawatan akan diberikan ke Sub Bagian Program dan Penganggaran untuk dikaji lebih lanjut baik secara teknis bangunan dan kebutuhan anggaran biaya. Setelah dilakukan pemeliharaan dan perawatan, data bangunan kemudian akan diserahkan ke Sub Bagian BMN untuk di input ke SIMAK BMN.

2. Unit (Fakultas) sebagai pengguna bangunan gedung dapat membuat usulan yang ditujukan ke Sub Bagian Program dan Penganggaran untuk dikaji lebih lanjut baik secara teknis bangunan dan kebutuhan anggaran biaya. Dari Sub Bagian Program dan Penganggaran kemudian meneruskan ke Sub Bagian Rumah Tangga, kemudian akan diproses dengan mempertimbangkan anggaran dan tingkat prioritas kebutuhan akan perawatan dan pemeliharaan. Jika diketahui anggaran yang ada di Unit masih tersedia, maka akan direkomendasikan kembali kepada Unit untuk melakukan pemeliharaan dan perawatan dengan anggaran yang ada di Unit. Namun, jika anggaran yang ada di Unit sudah tidak ada, dan anggaran yang tersedia di Sub Bagian Rumah Tangga masih mencukupi untuk melakukan pemeliharaan dan perawatan, maka akan langsung ditindaklanjuti Sub Bagian Rumah Tangga. Setelah 
JURNAL KACAPURI

JURNAL KEILMUAN TEKNIK SIPIL

Volume 4 Nomor 2 Edisi Desember 2021

dilakukan pemeliharaan dan perawatan, data bangunan kemudian akan diserahkan ke Sub Bagian BMN untuk di input ke SIMAK BMN.

Skema perawatan dan pemeliharaan bangunan gedung di Universitas Palangka Raya dapat dilihat pada gambar.

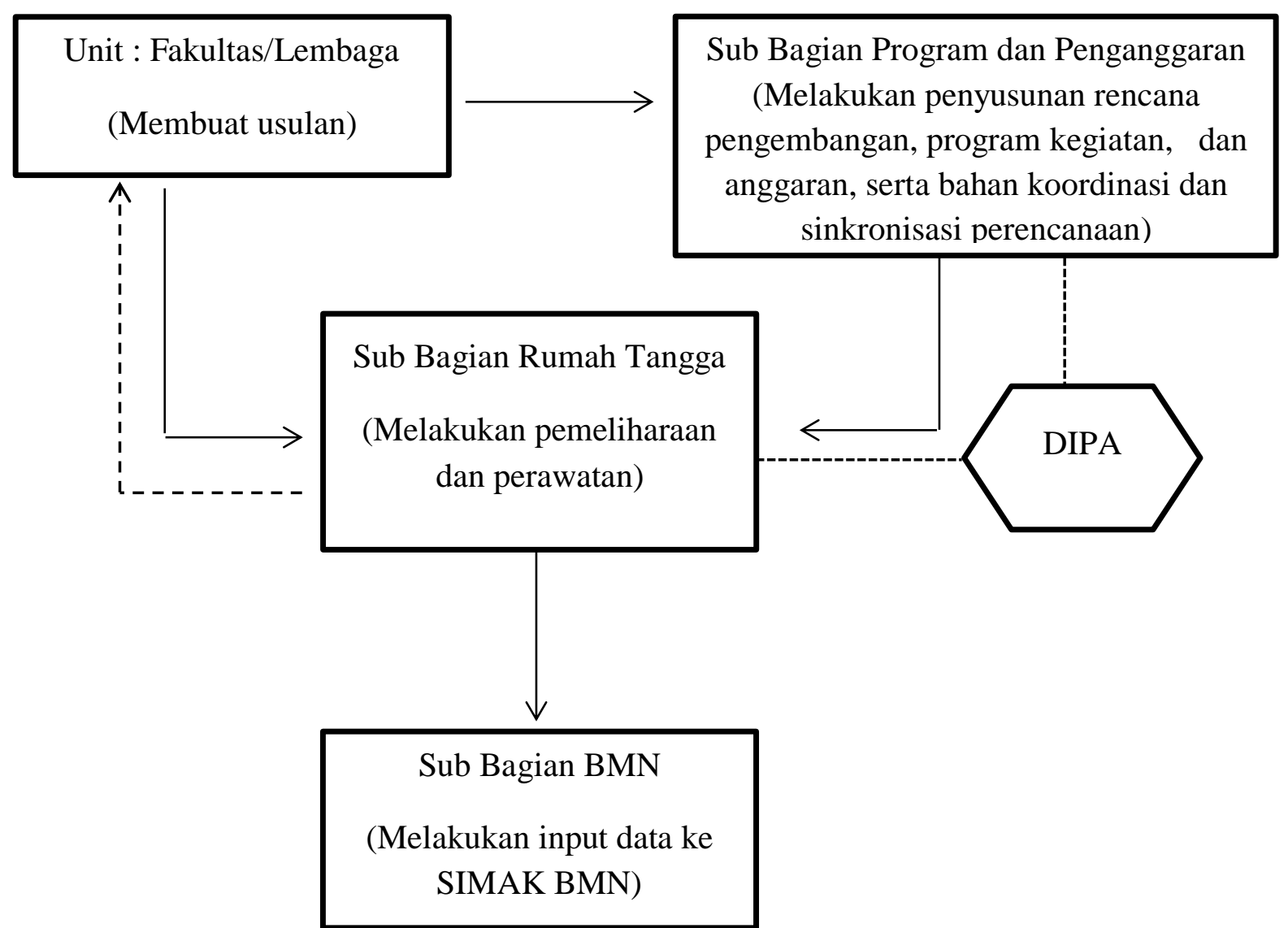

Gambar 1. Skema Manajemen Pemeliharaan dan Perawatan Bangunan Gedung Universitas Palangka Raya

Sumber : Hasil Penelitian

Tabel 1. Perbandingan Manajemen Pemeliharaan dan Perawatan Bangunan Gedung di UPR dengan PermenPU No. 24 Tahun 2008

\begin{tabular}{|l|c|c|c|c|}
\hline $\begin{array}{c}\text { Manajemen Pemeliharaan dan } \\
\text { Perawatan Bangunan Gedung }\end{array}$ & \multicolumn{2}{|c|}{$\begin{array}{c}\text { PermenPU No. 24 } \\
\text { Tahun 2008 }\end{array}$} & \multicolumn{2}{c|}{$\begin{array}{c}\text { Universitas } \\
\text { Palangka Raya }\end{array}$} \\
\hline & Ada & $\begin{array}{c}\text { Tidak } \\
\text { Ada }\end{array}$ & $\begin{array}{c}\text { Tidak } \\
\text { Ada }\end{array}$ \\
\hline Struktur Organisasi & $\sqrt{ }$ & & & $\sqrt{ }$ \\
\hline $\begin{array}{l}\text { SOP (Standard Operation } \\
\text { Precedure) }\end{array}$ & $\sqrt{ }$ & & & $\sqrt{ }$ \\
\hline Program Kerja & $\sqrt{ }$ & & $\sqrt{ }$ & \\
\hline Jadwal Pemeriksaan Berkala & $\sqrt{ }$ & & & $\sqrt{ }$ \\
\hline Tenaga Ahli/Tenaga Terampil & $\sqrt{ }$ & & $\sqrt{ }$ & \\
\hline
\end{tabular}

Sumber : Hasil Penelitian 


\section{PENUTUP}

\section{Kesimpulan}

Berdasarkan hasil penelitian yang telah diperoleh, maka dapat dibuat kesimpulan sebagai berikut:

1. Berdasarkan dari fungsi bangunan gedung, Universitas Palangka Raya memiliki bangunan gedung dengan fungsi hunian, fungsi usaha, fungsi sosial dan budaya, dan fungsi keagamaan.

2. Dalam pelaksanaan pemeliharaan dan perawatan bangunan gedung, UPR sudah melakukan pemeliharaan dan perawatan bangunan gedung dengan rutin dan baik.vDalam manajemen pemeliharaan dan perawatan bangunan gedung, UPR belum menerapkan Peraturan Menteri PU No. 24 Tahun 2008 tentang Pedoman Pemeliharaan dan Perawatan Bangunan Gedung secara keseluruhan, hal ini dapat dilihat dari belum adanya Struktur Organisasi Perawatan dan Pemeliharaan Bangunan Gedung di Universitas Palangka Raya, belum adanya SOP (Standart Operational Procedure), dan Jadwal Pemeriksaan Berkala.

\section{Saran}

1. Perlu adanya evaluasi dan pembaruan dalam manajemen perawatan dan pemeliharaan bangunan gedung, aset dan fasilitas di Universitas Palangka Raya berdasarkan peraturan yang berlaku. Usulan pembaruan yang dapat dijadikan bahan pertimbangan antara lain: struktur organisasi, SOP (Standart Operational Procedure), jadwal pemeriksaan berkala, sistem manajemen pemeliharaan dan perawatan yang terkomputerisasi.

2. Penelitian selanjutnya dapat menggunakan hasil penelitian ini sebagai acuan dengan berfokus pada jadwal pemeriksaan berkala dan sistem manajemen pemeliharaan dan perawatan yang terkomputerisasi.

\section{DAFTAR PUSTAKA}

Afifudin, Beni Ahmad Saebani., 2009. Metodologi Penelitian Kualitatif. Pustaka Setia. Bandung.

Arafat, M. Fathan., 2015. Pemeliharaan dan Perawatan Gedung Fakultas Teknik Universitas Jember. Universitas Jember. Jawa Timur.

Departemen Pekerjaan Umum., 2002. Peraturan Menteri Pekerjaan Umum Nomor 28 Tahun 2002 tentang Bangunan Gedung. Kementerian Pekerjaan Umum. Jakarta.

Departemen Pekerjaan Umum., 2008. Peraturan Menteri Pekerjaan Umum Nomor 24 Tahun 2008 tentang Pedoman Pemeliharaan dan Perawatan Bangunan Gedung. Kementerian Pekerjaan Umum. Jakarta.

Elia, Andrie., 2019. Rencana Strategis Universitas Palangka Raya Tahun 2020 2024. Universitas Palangka Raya. Palangka Raya.

Griffin, Ricky W., and Moorhead, Gregory., 2014. Organizational Behavior Managing People and Organizations. Eleventh Edition. USA/.

Kementerian Pendidikan dan Kebudayaan Republik Indonesia., 2015. Peraturan Menteri $R \quad$ iset, Teknologi, dan Pendidikan Tinggi Republik Indonesia Nomor 47 Tahun 2015 tentang Organisasi dan Tata Kerja Universitas Palangka Raya. Jakarta. 